TAO, Vol. 16, No. 5, 1097-1120, December 2005

\title{
Characteristic Trace Fossils from Shoreface to Offshore Environments of an Oligocene Succession, Northeastern Taiwan
}

\author{
Wen-Shan Chen ${ }^{1, *}$
}

(Manuscript received 22 December 2003, in final form 25 July 2005)

\begin{abstract}
Well-exposed Oligocene strata of the Hsuehshan Range in Taiwan were deposited in the Hsuehshan Trough along the eastern Eurasia continental margin. The Hsuehshan Trough was a restricted epeiric basin confined by a series of horsts. The Oligocene succession records a deepening-upward to shallowing-upward sequence of deltaic deposystems associated with fluvial and shallow marine environments. These environments ranged from wavedominated delta-plain through storm-dominated delta-slope to regressive tidedominated delta-front environments. The fining-upward to coarsening-upward sequence can be divided into five lithofacies and five ichnocoenoses. Ichnocoenoses characterized by Ophiomorpha, Cylindrichnus, Teichichnus, Scolicia, and Zoophycos were defined on the basis of assemblages, degree of bioturbation, diversity, and abundance.

The Lower Oligocene deposits exhibit a fining-upward trend and upward increases trend in bioturbation and abundance of deposit-feeding structures. Accompanying these changes is a transition from Ophiomorpha, Cylindrichnus, Teichichnus, Scolicia to Zoophycos ichnocoenoses, which also suggests a transgressive system from delta-plain to prodelta-slope environment. The sequential variation in lithofacies and ichnofossil assemblages coincides with changes in Early Oligocene sea level. The Upper Oligocene deposits show a shallowing-upward succession that suggests an evolution from a storm-dominated prodelta slope to a tide-dominated delta plain. The ichnofossil assemblages show a transition from Scolicia, Teichichnus to Ophiomorpha ichnocoenoses that are suggestive of regressive systems. The sequential trends documented in the Late Oligocene deposits of northeastern Taiwan are not consistent with global sea-level fluc-
\end{abstract}

\footnotetext{
${ }^{1}$ Department of Geosciences, National Taiwan University, Taipei, Taiwan, ROC

* Corresponding author address: Prof. Wen-Shan Chen, Department of Geosciences, National Taiwan University, Taipei, Taiwan, ROC;E-mail: wenshan@ntu.edu.tw
} 
tuations and therefore, tectonic processes are invoked to have controlled local basin conditions. In general, the sequential variations documented in the Oligocene strata probably were controlled by paleoceanographic conditions that were closely linked to tectonic processes and longer-term, firstorder sea-level fluctuations.

(Key words: Trace fossil, Oligocene, Hsuehshan Range, Sea-level fluctuation)

\section{INTRODUCTION}

Oligocene fluvial and shallow marine deposits containing a diverse assemblage of body fossils as well as physical and biogenic structures are widely exposed in the Hsuehshan Range, Taiwan (Fig. 1). The study area, located along the northeastern coast of Taiwan, has excellent exposures of Oligocene strata that provide an opportunity for detailed sedimentological analysis of deposystems and ichnofacies. Strata are composed of shoreface to offshore marine wave,

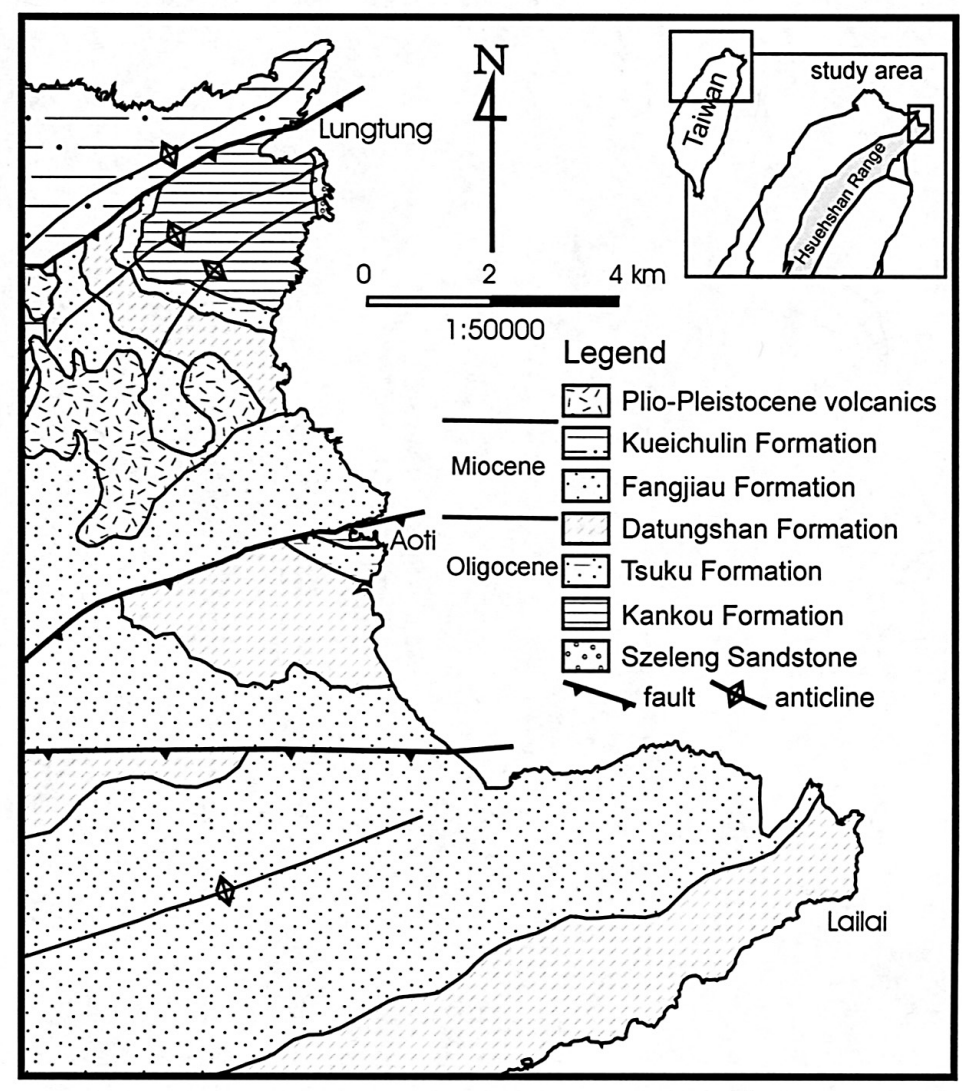

Fig. 1. Geologic map of the northeastern coast of Taiwan. 
tide, and storm deposits that record transgressive and regressive events. Few previous studies have focused on the reconstruction of these depositional environments. By analyzing both sedimentary structures and trace fossils, a more accurate reconstruction of both syndepositional and post-depositional environmental conditions is possible. Sedimentary structures alone, however, do not allow sedimentologists to recognize the post-depositional history of sedimentary rocks. In the last three decades, paleontologists and sedimentologists increasingly have refined the use of ichnofossils as paleoenvironmental indicators. The combination of ichnology with sedimentology has improved environmental interpretations for factors such as bathymetry, salinity, oxygenation, and relative rates of deposition (Frey and Howard 1985; Wignall and Myers 1988). The Oligocene succession of northeastern Taiwan, which contains several different lithofacies and well-defined ichnofacies, ideally is suited for delineating sedimentological environments because of the excellent exposures. In this study, new sedimentologic and biologic data along with ichnofossil assemblages are used to reconstruct the depositional environments of the eastern Eurasia continental margin during the Oligocene.

\section{GEOLOGIC SETTING}

Paleogene rocks are broadly distributed throughout Taiwan, where widespread thick Cenozoic deposits unconformably overlie late Mesozoic basement (Yuan et al. 1985). At the beginning of the late Cretaceous, the region in what is now Taiwan underwent extension associated with the opening of the South China Sea (Teng 1992). Extensional deformation resulted in the formation of numerous half-graben basins that were filled with sediments derived from southeast Mainland China during Eocene to Miocene. The Paleogene deposits of the Hsuehshan Range and offshore in the Taiwan Strait are estimated to be more than $4000 \mathrm{~m}$ thick. These strata were deposited in fluvial and marine environments, ranging from an alluvial- and wavedominated delta plain through a storm-dominated prodelta slope to a tide-dominated delta front. The thick, shallow-marine deposits indicate active subsidence during deposition.

The post-middle Miocene geologic history of Taiwan was heavily affected by convergent tectonics due to the collision between the Luzon volcanic arc and the Eurasian continent. Regional shortening associated with collisional deformation led to uplift of Paleogene strata and produced the excellent exposures in the Hsuehshan Range. Foraminifera biostratigraphy (Huang and Cheng 1983) and paleoecology of molluscan fauna (Lee 1983) provide a stratigraphic framework.

\section{SEDIMENTARY STRUCTURES AND TRACE FOSSILS}

The study area is $\sim 20 \mathrm{~km}$ long and bordered by a narrow coastal erosional-platform that corresponds to the northern tip of the Hsuehshan Range (Fig. 1). Underlying these rocks are folded Oligocene-Miocene strata that were subdivided by Tang and Yang (1976) into the Szeleng, Kankou, Tsuku, Datungshan, and Fangjiao Formations. The deepening-upward to shallowing-upward succession consisting of conglomerate, sandstone, rhythmic sandstone/ shale and intensely bioturbated sandstone characterize these strata. These rocks are about $1700 \mathrm{~m}$ 
thick, and have been deformed and slightly metamorphosed. As documented below, the succession can be divided into six facies associations, which are broadly interpreted to have been deposited along a shoreface to offshore gradient.

Trace fossils are abundant within the widespread outcrops of the Oligocene succession. The ichnofacies study presented here is combined with sedimentary structure, paleontological, and chemical data to better reconstruct the depositional environments (Moslow and Pemberton 1988; Frey et al. 1990). This study only deals briefly with ethologic description, and places more emphasis on integrating the characteristics of bioturbation, ichnodiversity, trace fossil abundance, and sedimentary structures. As indicated previously, there is an intimate relationship between trace fossils and lithofacies and allows recognition of five ichnocoenoses.

\subsection{Ophiomorpha Ichnocoenosis}

Lithologically, ichnocoenosis occurs in pebbly sandstone and sandstone associations. The pebbly-sandstone association of the lower Szeleng Sandstone comprises thick-bedded, moderately to well-sorted, coarse-grained sandstone and pebbly sandstone with large-scale crosslaminae, parallel-laminae (Fig. 2), and, less commonly, swaley and symmetrical megaripples. Swaley cross-stratification reflects storm-dominated deposition above fair-weather wave base that developed as large-scale composite sandwaves (Leckie and Walker 1982; Colquhoun 1995). Individual beds are about 0.5 to $1.0 \mathrm{~m}$ thick, exhibiting basal bounding surfaces marked by a lag of winnowed pebbles. The erosional bases display gently undulatory surfaces with maximum relief of $0.5 \mathrm{~m}$. The near-shore environment is dominated by fair-weather deposits interrupted occasionally by erosive surfaces formed by the effect of storms (Rossetti 1997). Throughout, lithofacies consists mainly of unidirectional cross-laminae. The sedimentary structures reflect wave influence that indicates intense reworking of fair-weather deposits during storms. Variations in facies association reflect the positions of the sections with respect to a nearshore-shoreface environment (Mueller and Dimroth 1987; Tai and Teng 1994).

The sandstone association of the Fangjiao Formation is characterized by thick-bedded, well-sorted sandstone, alternating with rhythmic beds that show herringbone cross-stratification (Fig. 3), wavy, and flaser structures. Unidirectional trough cross-laminae are pervasive throughout the sandstone, with individual sets being 0.3 to $1 \mathrm{~m}$ thick. Mudstone drapes on foresets suggest tidal influence (Richards 1994; Corcoran et al. 1998). In rare cases, sandstones show cross-laminae in a direction opposite to the dominant flow direction. Ripplelaminated sands with well-developed mud drapes interbedded with lenticular- and flaser-bedded deposits are common. Sparse lags contain abundant mud clasts and rare plant debris, usually found in the troughs of erosion surfaces. The erosional surfaces may have a basal lag of shale pebbles, which are interpreted as tide-dominated channel-fill deposits (Savrda et al. 1998). The sandstone facies represents deposition in a subtidal-intertidal environment.

Only a few trace fossils occur in this lithofacies, which is dominated by physical sedimentary structures (Fig. 4). Sedimentary structures indicate that relatively high-energy conditions prevailed during frequent erosion and deposition on a marine substrate within a littoral-sublittoral zone. Trace fossils are usually sparse in the sandstone and pebbly sandstone beds, but abundant in a few of the sandstone beds (Fig. 5). All preserved trace fossils are vertical burrows; 


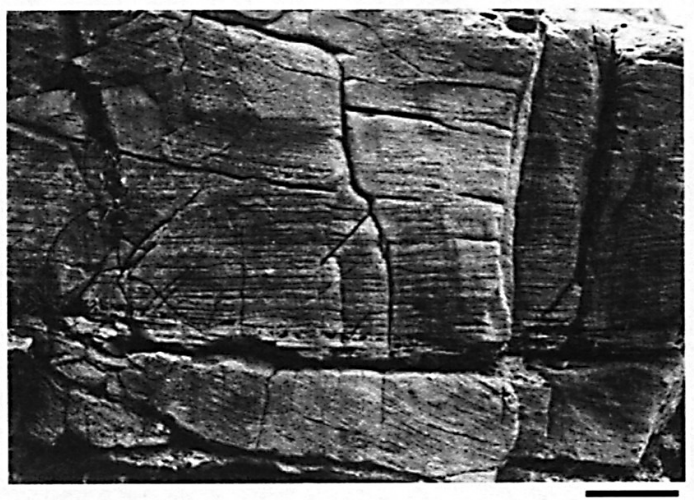

Fig. 2. Thick-bedded sandstones show planar cross- and parallel-laminae structures. Scale bar $=20 \mathrm{~cm}$.

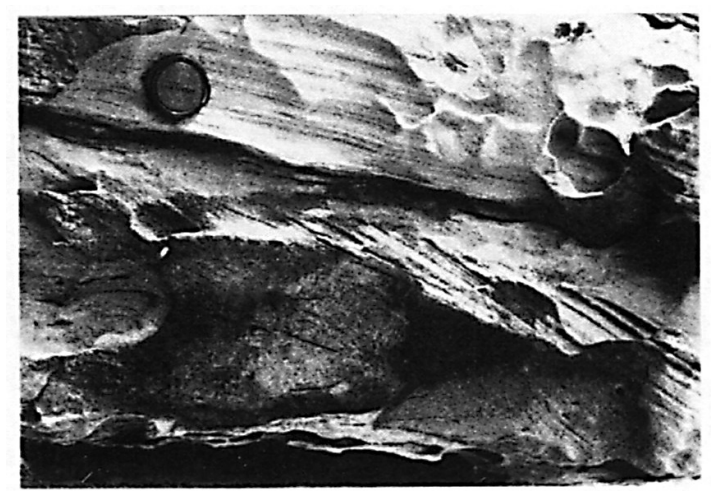

Fig. 3. Thick-bedded sandstones show trough cross-laminae, herringbone crosslaminae and parallel-laminae structures. Lens cap $=6.5 \mathrm{~cm}$.

no shallow-tier tracks or trails were recognized. The Ophiomorpha ichnocoenosis is associated mainly with large-scale cross- and parallel-laminated structures in which Ophiomorpha nodosa (Fig. 6a) and Skolithos isp. are present. The configuration of Ophiomorpha isp. has been used as an environmental indicator. Predominant vertical elements reflect high-energy conditions, whereas domination by horizontal elements is more likely associated with lowenergy environments (Frey and Mayou 1971; Jones and Pemberton 1989). Here, Ophiomorpha nodosa is a prominent and striking vertical structure that commonly forms a low-abundance and -diversity ichnoassemblage (Figs. 7, 8) preserved in thick-bedded sandstones. The producers of both Ophiomorpha and Skolithos are interpreted as a stress-tolerant suspension feeder that was well adapted to nearshore environments. The fluctuating periods of deposition and erosion in the littoral-sublittoral zone resulted in the absence of shallow tiers (Bromley, 1990; Bromley and Asgaard, 1991). The Ophiomorpha ichnocoenosis is interpreted to reflect a well- 


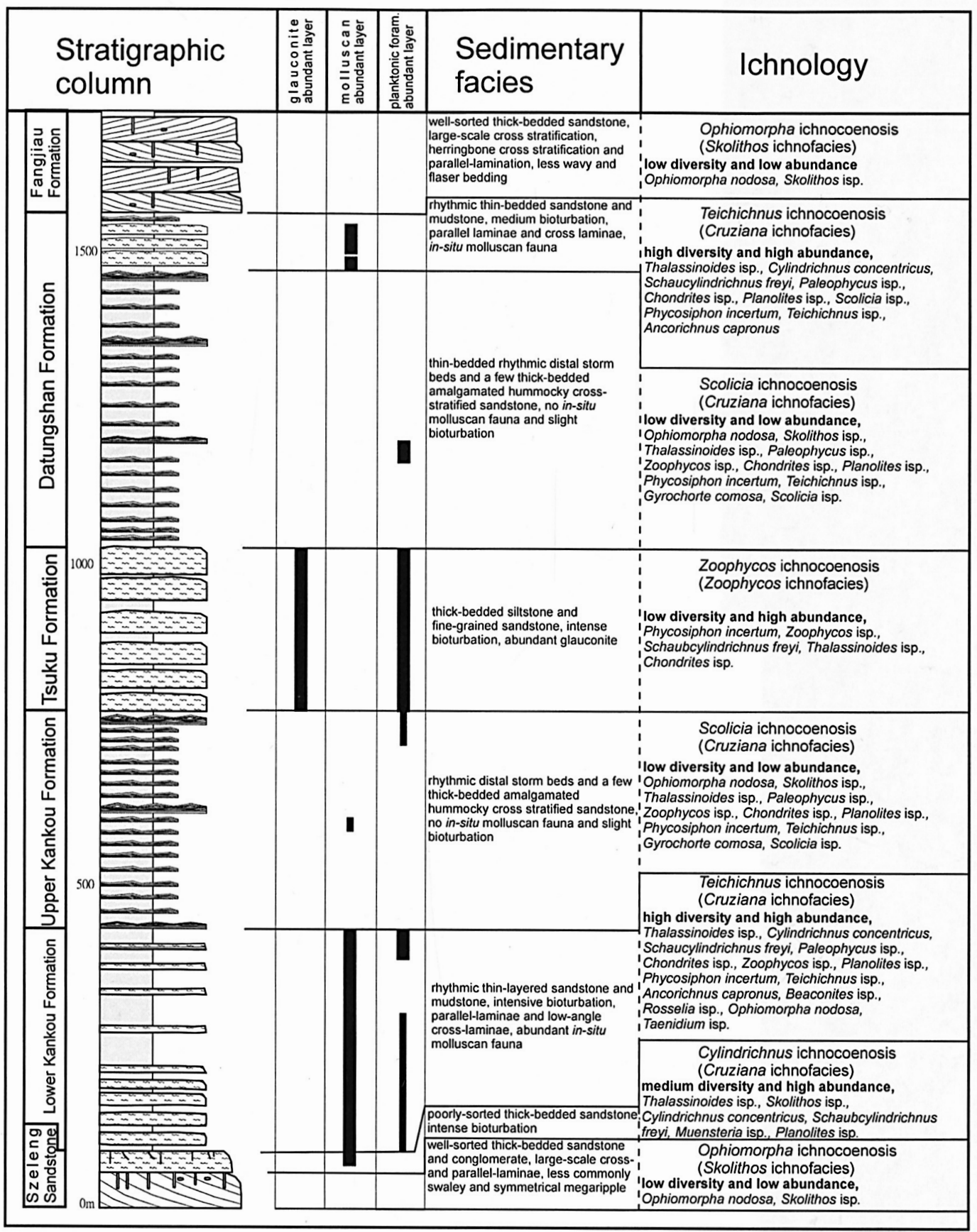

Fig. 4. Sedimentological log of Oligocene formations at northeastern coast section shows sedimentary facies, molluscan, planktonic foram and glauconite data and compared to ichnologic composition. 


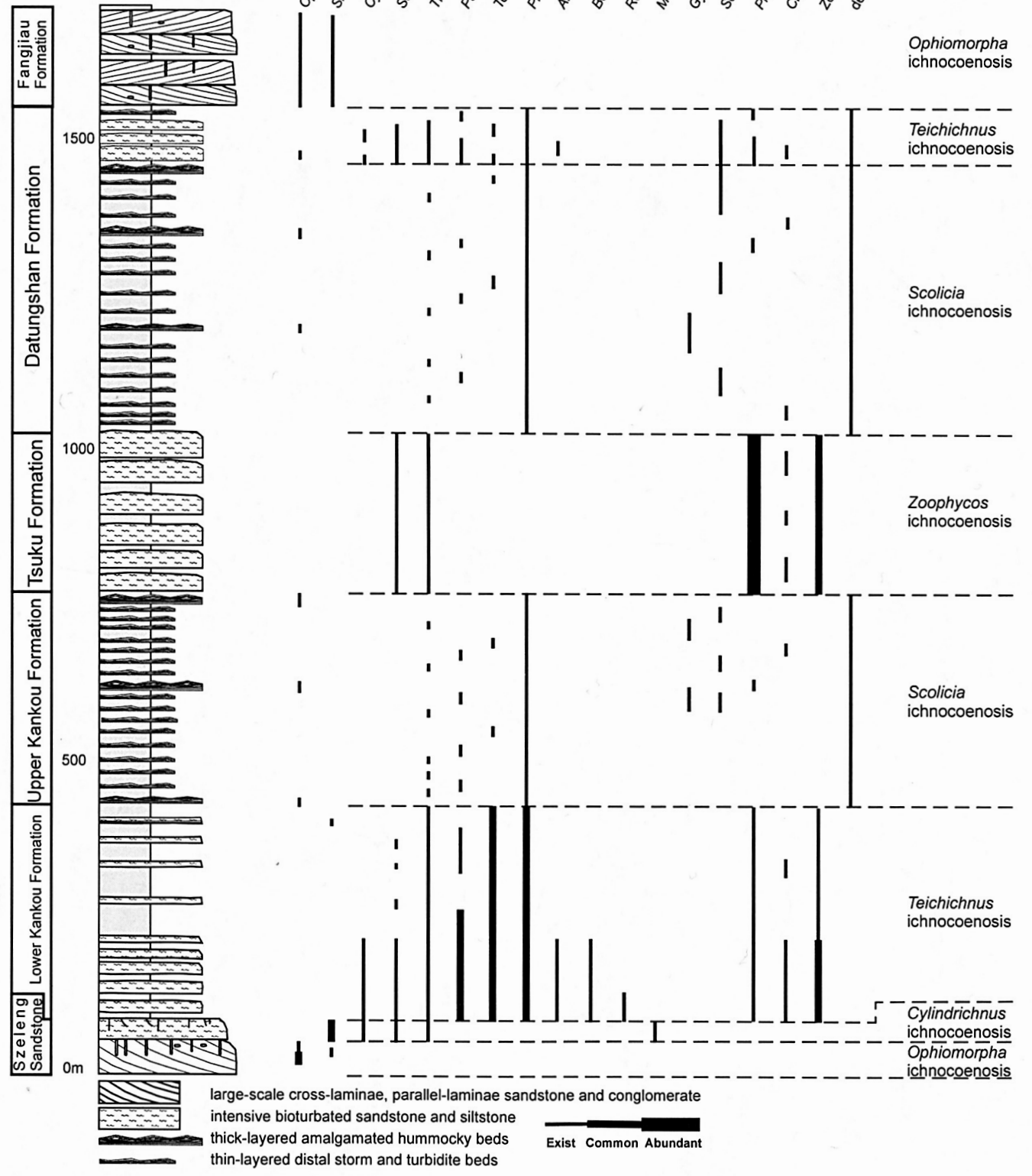

Fig. 5. Trace fossil composition of ichnocoenoses in the Oligocene formations. 

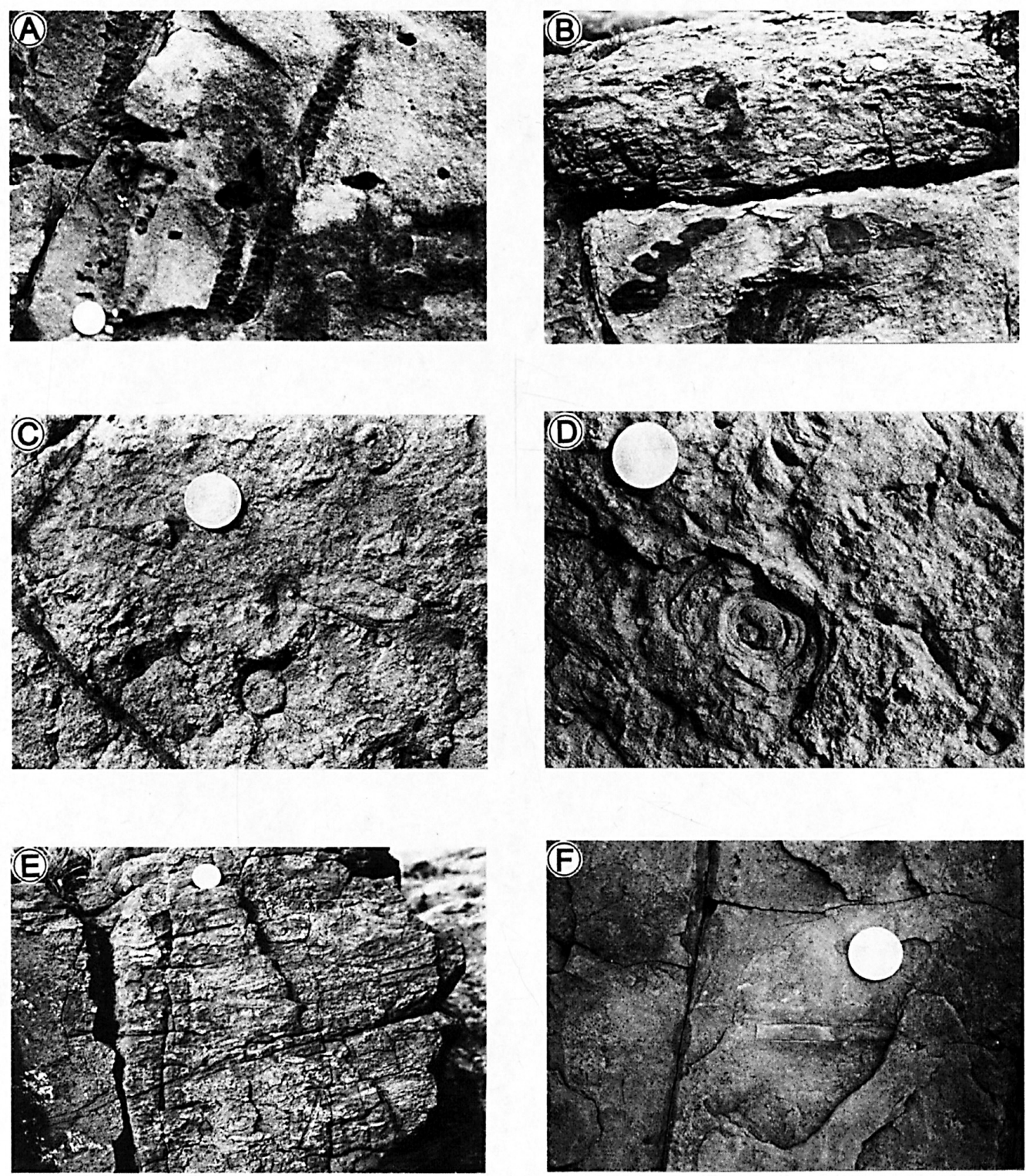

Fig. 6. (a) Vertical section view of Ophiomorpha nodosa from the lower Szeleng Sandstone. (b) The sandstone displays as poorly sorted and structureless with a high degree of bioturbation. (c) Bedding plane view of Skolithos isp. from the upper Szeleng Sandstone. (d) Cylindrichnus concentricus from the upper Szeleng Sandstone. (e) Bioturbated sandstone often obscures sedimentary structures by abundant deposit-feeders. (f) Paleophycus isp. from the lower Kankou Formation. Coin $=2.6 \mathrm{~cm}$. 


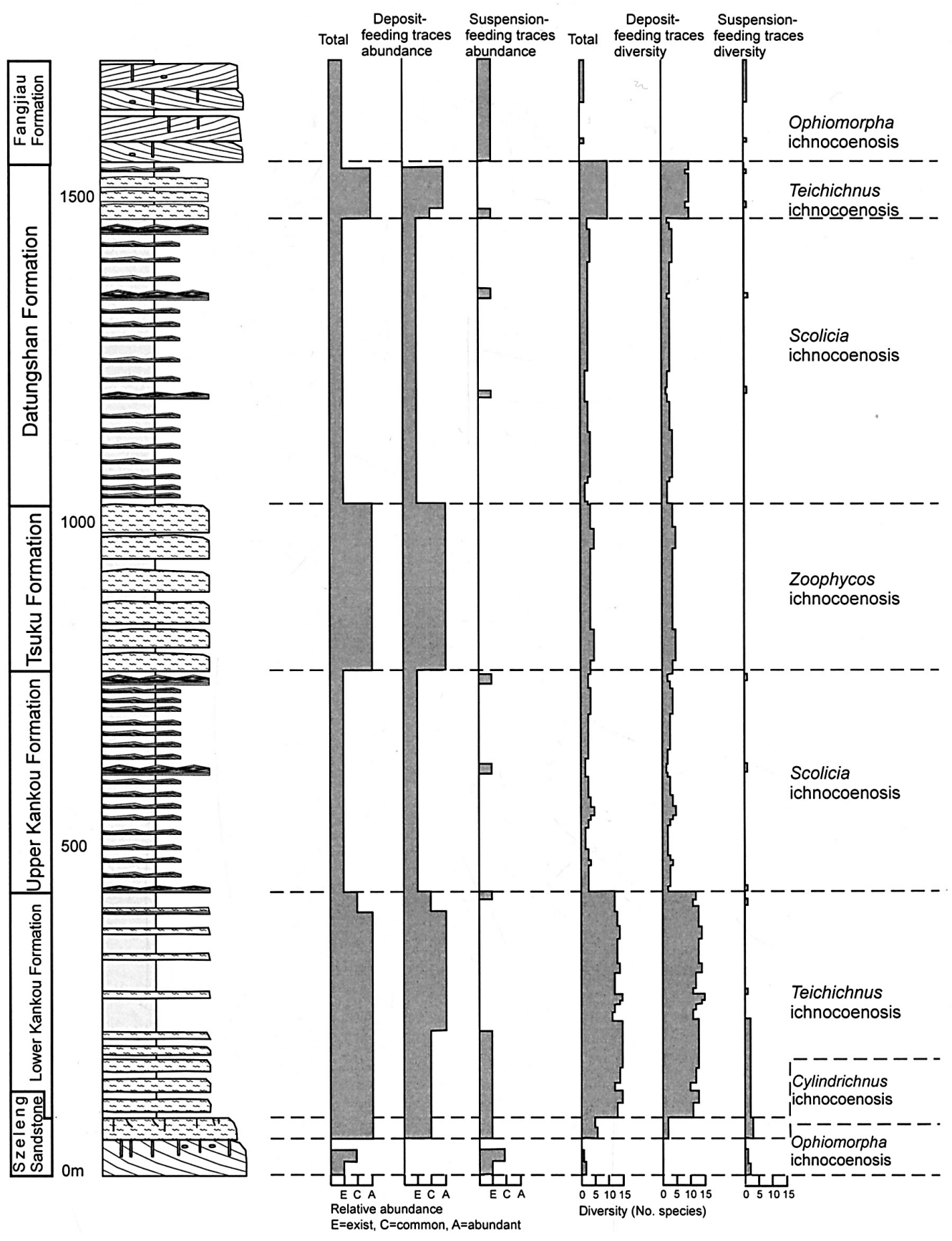

Fig. 7. Diversity (number of species) and abundance of trace fossils in various types of lithofacies. 


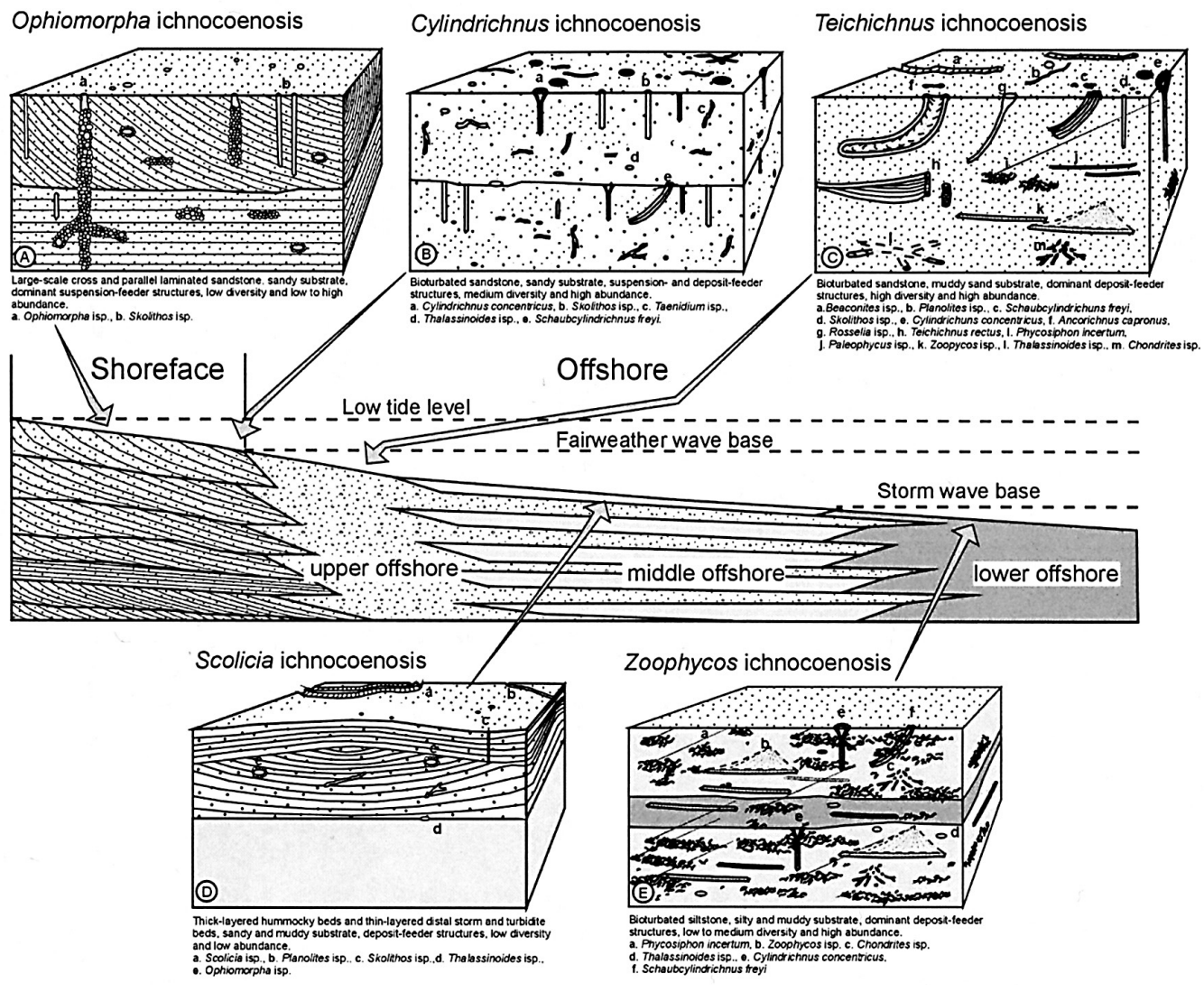

Fig. 8. Ichnofacies model of the Oligocene formations, showing the distribution of the sedimentary facies and ichnocoenoses. Reconstruction of (a) Ophiomorpha ichnocoenosis; (b) Cylindrichnus ichnocoenosis; (c) Teichichnus ichnocoenosis; (d) Scolicia ichnocoenosis; and (e) Zoophycos ichnocoenosis. Not to scale.

aerated, high-energy environment with abundant suspended food, probably above fair-weather wave base. Such an ichnocoenosis is similar to Seilacher's (1964) "Skolithos ichnofacies", which is often interpreted to represent high-energy wave- and tide-dominated, littoral-sublittoral environments.

\subsection{Cylindrichnus Ichnocoenosis}

The sediments containing the Cylindrichnus ichnocoenosis consist of intensely bioturbated thick-bedded (0.5 - $1.0 \mathrm{~m})$ sandstone (Figs. 4, 6b). The bioturbated sandstone of the upper 
Szeleng Sandstone is medium- to coarse-grained and poorly sorted, having abundant invertebrate detritus. Biogenic structures are composed mainly of vertical burrows. Thick-bedded sandstone, probably caused by intense bioturbation, may have originally been interbedded sandstone and shale. In other words, benthos modified the substrate under waning energy conditions after sediments were initially deposited. The bioturbated sandstone often is interbedded with cross- and parallel-laminated sandstone in other sections (Chen 1986), and has been interpreted as the product of deposition just below fair-weather wavebase (Howard 1972; Chen 1986) or within lower-shoreface environments (Howard and Frey 1984). The lithofacies and biogenic structures point to a general environment between shoreface and offshore.

The Cylindrichnus ichnocoenosis consists of abundant and diverse ichnofossils in bioturbated sandstones. The most common ichnofossils are Skolithos isp. (Fig. 6c), Thalassinoides isp., Cylindrichnus concentricus (Fig. 6d), Schaubcylindrichnus freyi, Taenidium isp., and Planolites isp. (Fig. 5). These traces are mainly domichnia of suspension feeders, represented by Skolithos isp., Cylindrichnus concentricus and Schaubcylindrichnus freyi. The feeding burrows of deposit feeders are represented by Thalassinoides isp., and Planolites isp. The ichnoassemblage contains mainly domichnial vertical burrows, indicating that bottomwater circulation was sufficient to fully oxygenate the seafloor. In general, suspension-feeders show a slight propensity for coarser-grained sediments (Fursich 1975) under an alternating high- to low-energy environment. Following a storm, abundant benthos colonized the substrate that previously was bioturbated thoroughly during the post-storm periods. The next storm event ensued before the benthos was able to completely bioturbate the previously deposited storm sediment. Howard (1972) interpreted such an ichnocoenosis as representing alternating periods of storm and fair-weather conditions in an environment at or just below the fair-weather wavebase. The Cylindrichnus ichnocoenosis, therefore, is interpreted to be constituted by medium-diversity and high-abundance ichnofossil assemblages within an individual bed (Figs. 7, 8), which is represented by the Cruziana ichnofacies close to the fair-weather wave base (MacEachern et al. 1999; Fursich and Pandey 1999).

\subsection{Teichichnus Ichnocoenosis}

Feeding burrows characterize rhythmic thick-bedded sandstones and mudstones having gradational contacts; and bioturbation (Fig. 6e) obscures physical sedimentary structures (Figs. 4, 5 and 7). Nevertheless, it is still possible to find a few sedimentary structures present, including parallel-laminae, low-angle cross-laminae, and molluscan-detritus lags. These types of sedimentary structures are suggestive of storm deposits. Bioturbated sandstones are commonly thin-bedded and amalgamated in part and usually have bioturbated tops and lower parts that retain parallel and low-angle cross-laminae.

The thick-bedded mudstones in this ichnocoenosis are bioturbated thoroughly and contain abundant in situ molluscan fauna of mostly a shallow marine affinity (Lee 1983). Molluscs generally occupy a position at or beneath the seafloor, and indicate an oxygenated environment. Much of the molluscan detritus along the sandstone bases was deposited originally as storm-deposited lags, rather than as storm current deposits. The intensely bioturbated 
sandstones are postulated to be storm-emplaced. Hence, this ichnocoenosis is interpreted as having been deposited below the fair-weather wavebase in the upper offshore environment. Nevertheless modification of molluscan detritus exhibited a random orientation of shell fragments; and these features are interpreted as the result of subsequent bioturbation (Fursich and Pandey 1999).

The Teichichnus ichnocoenosis is characterized by completely bioturbated sandstones and mudstones containing diverse and abundant, well-preserved trace fossils (Fig. 8) including Thalassinoides isp., Cylindrichnus concentricus, Schaubcylindrichnus freyi, Paleophycus isp., Chondrites isp., Zoophycos isp., Planolites isp., Phycosiphon incertum, Teichichnus rectus, Ancorichnus capronus, Rosselia isp., Ophiomorpha nodosa, and Taenidium isp. (Figs. 4, 5). Although individual identification and quantitative analysis are not straightforward,Thalassinoides isp., Cylindrichnus concentricus, Paleophycus isp. (Fig. 6f), Schaubcylindrichnus freyi (Fig. 9a), Planolites isp., and Teichichnus rectus (Fig. 9b) are most common. Zoophycos isp. is locally common also. This association consists mainly of horizontal trace fossils presumably produced by deposit feeders, and a few oblique and vertical burrows considered to be the work of suspension feeders. Other vertical burrows in this ichnoassemblage, such as Ophiomorpha nodosa and Skolithos isp., rarely are observed through the entire ichnocoenosis. Ophiomorpha nodosa and Skolithos isp. commonly occur in storm beds, representing dwelling structures of suspension feeders during waning energy conditions related to storm events. Abundant benthic fauna destroys the low-angle undulatory parallel-laminated sandstone in the post-storm depositional stage that is interpreted to reflect upper-offshore deposits (MacEachern et al. 1999). The Teichichnus ichnocoenosis is a high-diversity and low- to high-abundance assemblage of trace fossils that characterize the Cruziana ichnofacies in the upper offshore (Howard and Frey 1984).

Zoophycos isp. is well preserved and more visible in completely bioturbated deposits of mixed-layer tiers. Zoophycos isp., produced by a deep deposit feeder, is emplaced within the deeper substrate in connection with an oxygenated seafloor and a coherent substrate (Olivero and Gaillard 1996). Appearance of a deeper tier of Zoophycos activity probably has obliterated the original deposit-feeder burrows. The substrate commonly ranges from fully oxygenated regions in shallow tiers into oxygen-deficient environments in deeper tiers. However, a few of the subhorizontal trace fossils such as, Taenidium isp., Thalassinoides isp., Planolites isp., and Teichichnus rectus, superimpose Zoophycos spreiten in bioturbated sandstone. The above ichnoassemblage, except Zoophycos isp., probably represents a dysaerobic environment. Possibly, erosion of the seafloor by storm events created a temporary aerobic environment during the post-storm that was hospitable to a few deposit-feeders.

\subsection{Scolicia Ichnocoenosis}

The Scolicia ichnocoenosis, ranging in thickness at individual beds from $1 \mathrm{~m}$ to a few centimeters, is composed mainly of rhythmic sandstone and shale, about $5-15 \mathrm{~cm}$ in individual sandstone bed thickness. These sandstones are predominantly thin-bedded storm-generated sandstone (Fig. 9c) and a few are thick-bedded amalgamated hummocky beds. Various sedimentary structures have been identified in current ripples, parallel laminae, small-scale 

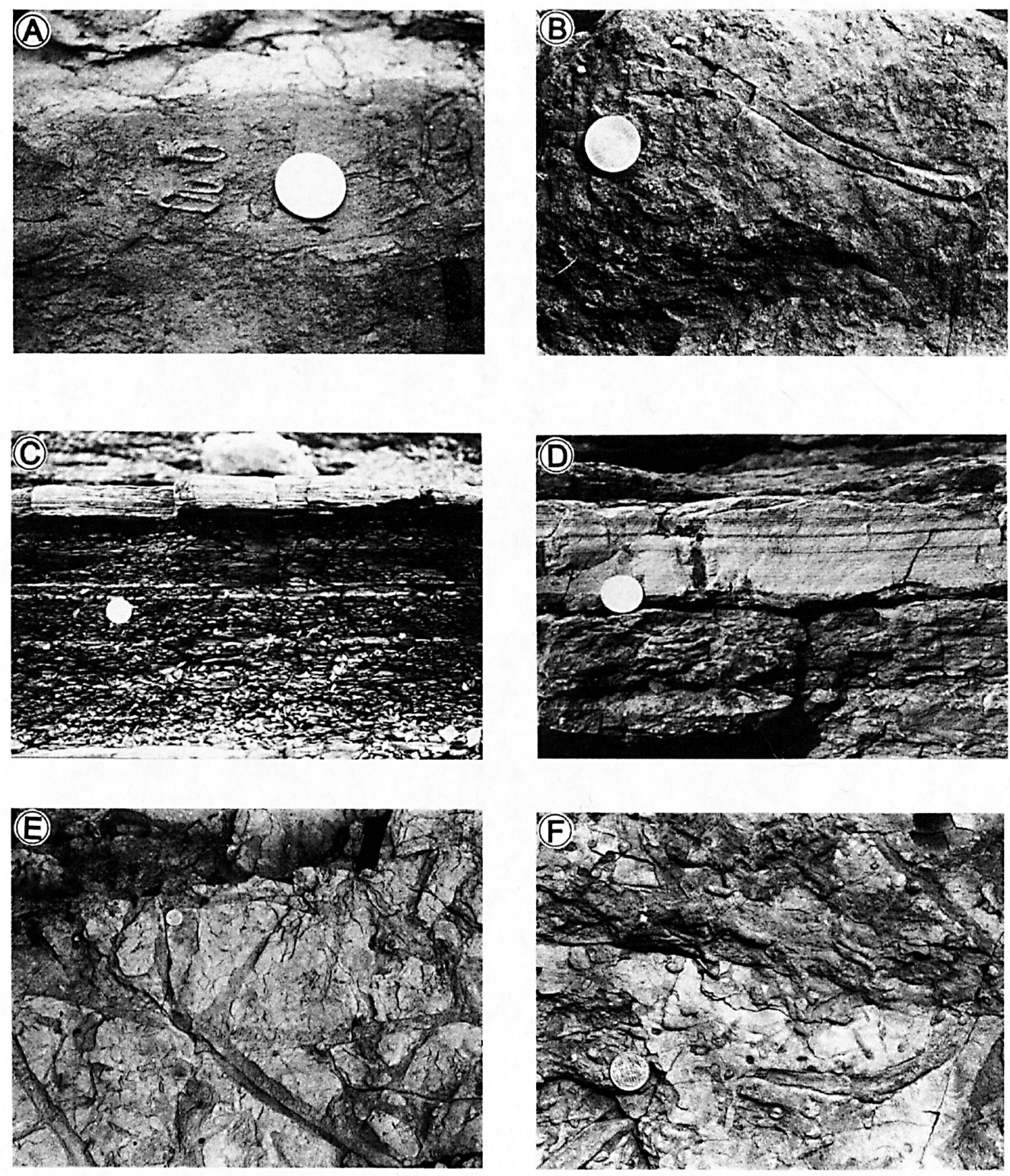

Fig. 9. (a) Schaubcylindrichnus freyi from the lower Kankou Formation. (b) Teichichnus rectus from the lower Kankou Formation; (c) Scolicia ichnocoenosis displays thin-bedded distal storm sandstone; (d) Thin-bedded storm beds show the parallel laminae and undirectional small-scale cross stratification; (e) Thalassinoides isp. from the upper Kankou Formation; (f) Paleophycus isp. from the upper Kankou Formation. Coin $=2.6 \mathrm{~cm}$. 
cross-laminae (Fig. 9d), and hummocky cross-stratification. The tops of thinner beds show straight-crested oscillation ripples and linguoid current ripples, demonstrating flow conditions in waning storms (Pfluger 1999). These beds have sharp and flat bases that are generally continuous across an outcrop, but some pinch out locally. The above sedimentary features indicate a storm origin. This lithofacies is interpreted as distal storm beds and turbidites that have been reworked by storm-induced traction currents (Johnson and Baldwin 1996). The ratio of sandstone to shale is low, and the amount of bioturbation is low. Thick-bedded amalgamated hummocky storm beds occur in medium-grained sandstone and are characterized by parallel-laminae, cross-stratification, and sharp bases. Hummocky undulations exhibit spacing of $1-3 \mathrm{~m}$. The generally accepted interpretation for hummocky storm beds is that they are produced by storm-induced traction and oscillatory currents (Duke 1985; Southard et al. 1990). This lithofacies association was probably deposited in shallow water below fair-weather wavebase but above storm wavebase (Cheel and Leckie 1993).

The Scolicia ichnocoenosis, usually devoid of molluscan body fossils, is associated with slightly bioturbated structures (Fig. 8) containing low diversity and low abundant assemblages (Fig. 7). More commonly individual biogenic structures can be recognized; most of these appear to be deposit-feeding structures. This ichnocoenosis typically displays sparse trace fossils in individual storm beds. The most common ichnofossils are Ophiomorpha nodosa, Skolithos isp., Thalassinoides isp. (Fig. 9e), Paleophycus isp. (Fig. 9f), Zoophycos isp., Chondrites isp., Phycosiphon incertum, Planolites isp. (Fig. 10a), Teichichnus isp., Gyrochorte comosa (Fig. 10b), Scolicia isp. (Fig. 10c), and dwelling structures (Figs. 4, 5). In the Scolicia ichnocoenosis, rhythmic sandstones and shales were deposited episodically by storms in an offshore environment with alternatingly high- and low-energy conditions. Sandstones also contain sparse Ophiomorpha nodosa, Skolithos isp., and other feeding and dwelling structures produced by suspension feeders formed during waning-energy conditions related to storm events. The sandstones regularly preserve Planolites isp., Scolicia isp., and dwelling structures on the top, and sparse Paleophycus isp. and Thalassinoides isp. at the base. This ichnoassemblage consists mainly of horizontal and oblique burrows of deposit feeders, indicating low-energy environments during post-storm deposition. This environmental interpretation is supported by the low-diversity and low-abundance trace fossil assemblage in an individual bed (Figs. 7, 8), which is characteristic of the Cruziana ichnofacies of the middle offshore (Howard and Frey 1984). The sandstone in this ichnocoenosis, however, resulted in a deposition under oxygen-deficient conditions that reflect periodic oxygenation episodes. The shale with very thin siltstone laminae a few millimeters thick, as a whole, rarely shows bioturbation and is devoid of molluscan fauna. Obviously, dysaerobic to anaerobic conditions existed in the post-storm depositional environment.

\subsection{Zoophycos Ichnocoenosis}

The Zoophycos ichnocoenosis occurs mainly as alternative $0.4-1.0 \mathrm{~m}$ thick-bedded bioturbated and structureless siltstones (Fig. 10d). In addition, slight grading and lag deposits are, for example, interpreted as storm-generated deposits in an offshore environment. In addition, this ichnocoenosis is intercalated with several horizons rich in glauconitic minerals and rela- 

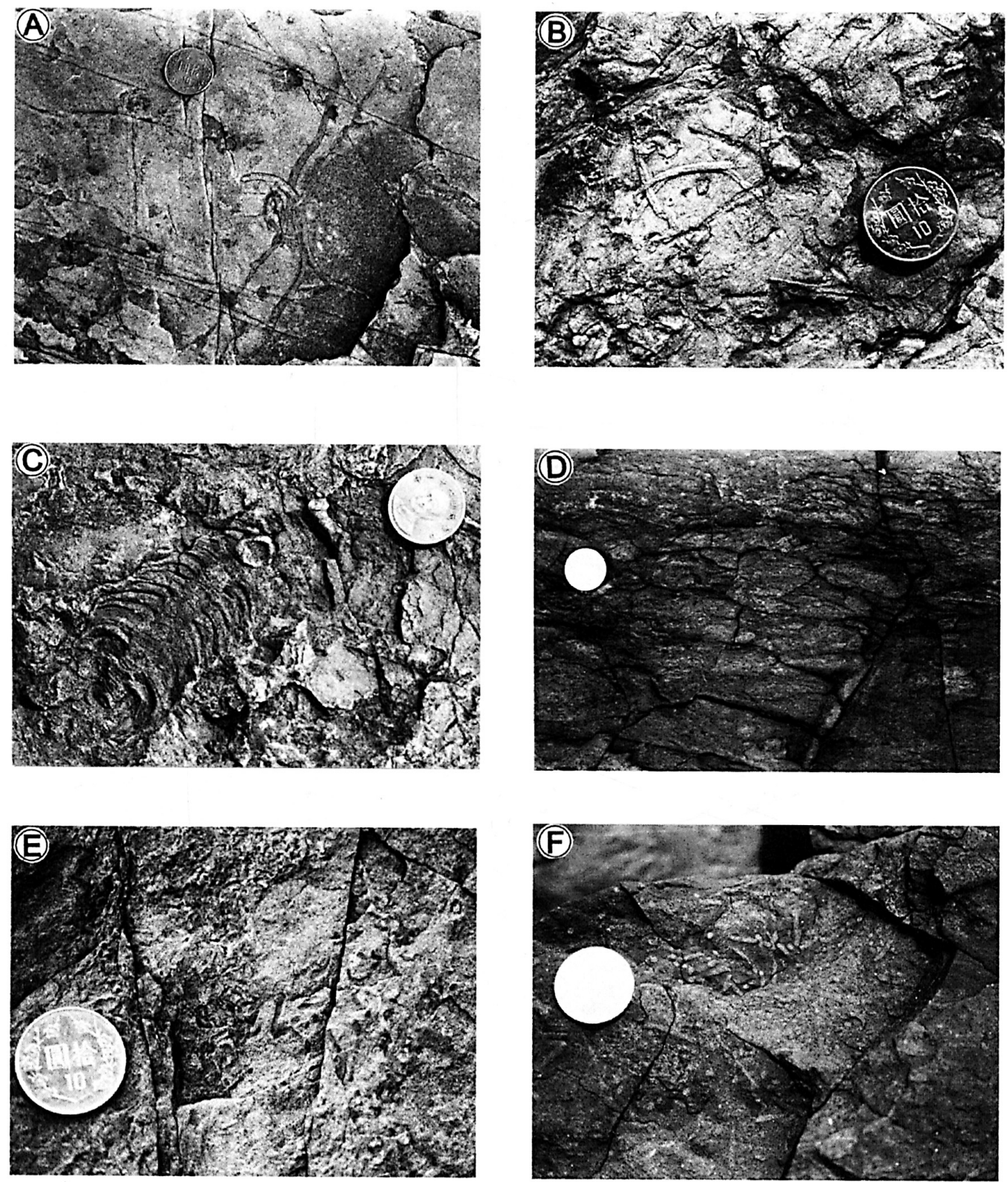

Fig. 10. (a) Planolites isp. from the upper Kankou Formation. (b) Gyrochorte comosa from the upper Kankou Formation; (c) Scolicia isp. from the upper Kankou Formation; (d) Zoophycos ichnocoenosis displays bioturbated beds mixed with thin-bedded siltstone; (e) Phycosiphon incertum from the Tsuku Formation; (f) Chondrites isp. from the Tsuku Formation. Coin $=2.6 \mathrm{~cm}$. 
tively deep-water benthic and planktonic foraminiferal assemblages (Huang and Cheng 1983; Tai and Teng 1994). Glauconite generally forms at the sediment-water interface and indicates slightly reducing conditions and lower sedimentation rates (Van Houten and Purucker 1984; Lin and Lin 1993; Burkhalter 1995). The lithofacies, therefore, may reflect dysaerobic conditions and lower sedimentation rates in post-storm environments.

The Zoophycos ichnocoenosis comprises a low-diversity assemblage of trace fossils consisting of Phycosiphon incertum (Fig. 10e), Chondrites isp. (Fig. 10f), Zoophycos isp. (Figs. 11, 12), Thalassinoides isp., Schaubcylindrichnus freyi, and Cylindrichnus concentricus (Figs. 4, 5). The ichnocoenosis is dominated by Phycosiphon incertum and Zoophycos isp., which are characterized by high abundance in an individual bed (Figs. 7, 8). Strongly bioturbated siltstones especially are characterized by an abundance of Phycosiphon incertum. Phycosiphon incertum consists of an unbranched, unlined, sinuous, subhorizontal, tiny, densely spaced and packed tunnel (Frey and Howard 1985; Ekdale and Lewis 1991; Miller and Vokes 1998), which is commonly confused with branching Chondrites isp. It represents the activity of a deposit-feeder at various tier depths and at variable water depths from lower shoreface to bathyal (Wetzel and Bromley 1994). Thalassinoides isp., Cylindrichnus concentricus, and Schaubcylindrichnus freyi occur in low abundance and are distributed sparsely in bioturbated siltstones. They are disturbed and superimposed by Phycosiphon incertum and Zoophycos isp., which represent opportunistic colonization during waning-energy conditions related to storm events. They provide a record of the activity of the earliest colonizers. A rapid deoxygenating event at the cost of aerobic to dysaerobic conditions during the post-storm event can be recognized based on their crosscutting relationships. In cases of high burrow density, the Zoophycos ichnocoenosis is composed of plentiful Phycosiphon incertum and Zoophycos isp. within glauconite-bearing beds that probably indicate dysaerobic post-storm conditions on the seafloor. Therefore, it is likely that Phycosiphon incertum in this case probably possessed a behavior to adapt to oxygen deficient conditions. This ichnocoenosis is not dissimilar to the Zoophycos ichnofacies, which is often interpreted to represent the normal low-energy environment below storm-wave base (Howard and Frey 1984; Bromley 1990).

\section{DISCUSSIONS}

The Early Oligocene deposits, as deduced from sedimentology, represent a transgressive sequence from the shoreface to lower offshore environment. Trace fossil associations from this succession can be divided into five ichnocoenoses in three ichnofacies. The distinguishing features of the ichnoassemblages are representative of the transition from the Skolithos ichnofacies to Zoophycos ichnofacies. The ichnocoenoses vary in ascending order from Ophiomorpha, Cylindrichnus, Teichichnus, Scolicia to Zoophycos ichnocoenoses.

The trace fossils in the succession generally are distinct and well preserved. Dominant suspension-feeder trace fossils such as Ophiomorpha nodosa, Skolithos isp., and Cylindrichnus concentricus are in the order of decreasing abundance (Fig. 5), probably reflecting decreasing seafloor water energy. In addition, the degree to which sediments have been bioturbated is also an indicator of physical energy and aeration of the environment. Bioturbated structures 


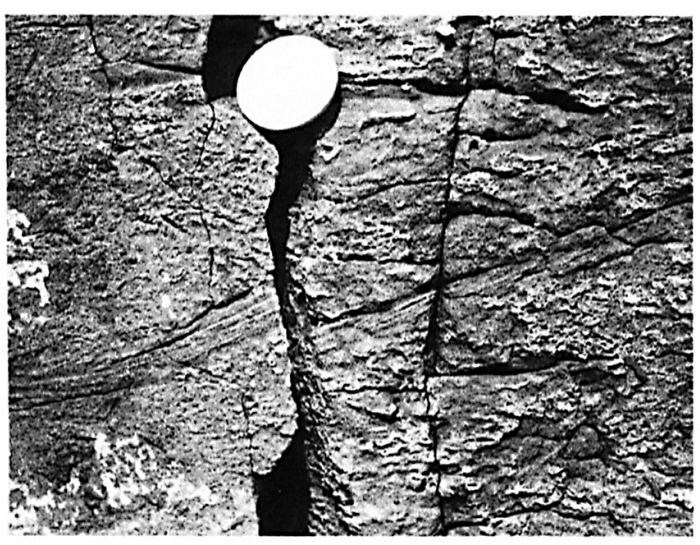

Fig. 11. Vertical section view of Zoophycos isp. Coin $=2.6 \mathrm{~cm}$.

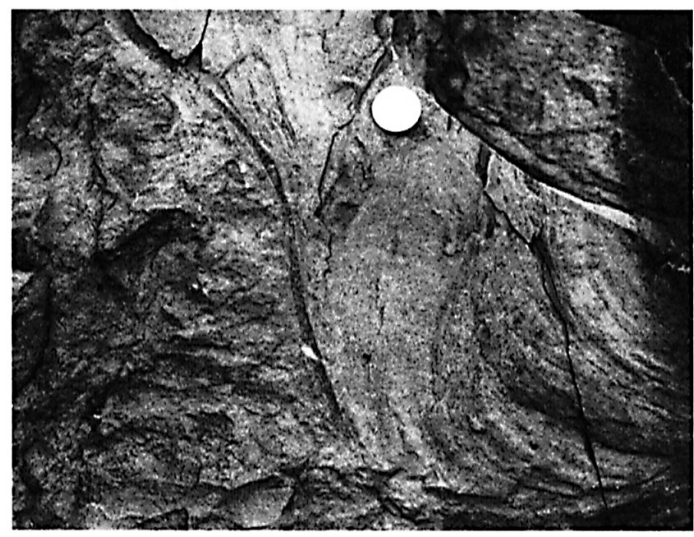

Fig. 12. Bedding plane view of Zoophycos isp. Coin $=6.5 \mathrm{~cm}$.

commonly increase from shoreface to offshore environments due to increasing benthos. This is especially true for the upper offshore and below fair-weather wavebase environments which are characterized by greater stability and lower-energy conditions with abundant organic detritus. The depositional environments of the Ophiomorpha ichnocoenosis are strongly influenced by hydraulic forces associated with wave action that induces agitation of bottom water along basin margins during the Eocene (Fig. 13a). Wave effects in general are significantly reduced at depths of about $20 \mathrm{~m}$ or more during fair weather. Furthermore, abundant biogenic structures almost completely replace sedimentary structures below a fair-weather wavebase. Therefore the muddy sandstone of the Teichichnus ichnocoenosis, thoroughly bioturbated with the deposit-feeder, is interpreted to reflect accumulation below fair-weather wavebase. In this 

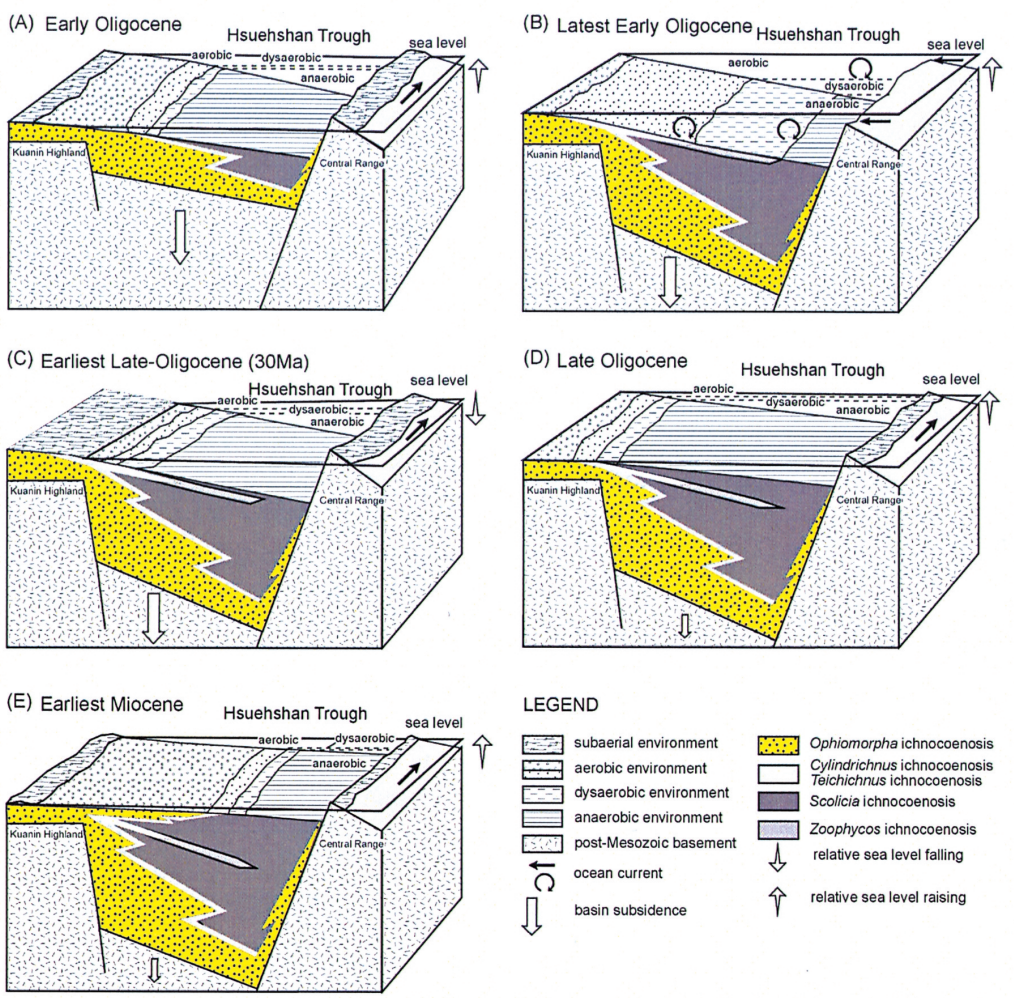

Fig. 13. Depositional model for Oligocene Formation in the Hsuehshan Range. (a) Rifting in the Eurasian continental margin created the Hsuehshan Trough enclosed by the surroundings horsts (the Kuanin Highland and paleo-Central Range). The Szeleng Sandstone was deposited by currents and waves transporting grave and sand that flowed west out of the continent and into the Hsuehshan Trough. Rapid subsidence along the Hsuehshan Range resulted in a transgressive deepening-upward sequence of the Kankou Formation. The trough was protected from open sea by horsts; (b) The trough becomes an open-sea environment resulting in the sea-level rising over the horsts during the latest Early Oligocene. Oceancurrent circulation induces the bottom water agitation, taking place with a broad charge from anaerobic to dysaerobic environment on the substrate; (c) The depositional environment occurs as slightly shallowing during the earliest Late Oligocene. Tectonics is a possible cause with relative change in sea level possibly being affected more by episodes of subsidence than by eustatic change; (d) The Upper Oligocene deposits represented a coarsening- and shallowing-upward sequence that was gradually deposited by terrigenous sediments in this basin; (e) The Hsuehshan Trough was filled by sediments during the earliest Miocene. 
study, it was commonly observed that the Ophiomorpha ichnocoenosis occurs above fairweather wavebase and the Cylindrichnus ichnocoenosis near this depth and the Teichichnus ichnocoenosis below this depth.

Occurrence of the Scolicia ichnocoenosis with thin-bedded tempestites is related to periodic storm deposits. A low-diversity and low-abundance association of trace fossils, formed by deposit-feeders in sandstone beds, reflects an opportunistic bottom fauna. The absence of macrobenthos and plankton within shales suggests that the substrate and water masses were generally in anaerobic conditions (Pfluger 1999). Thus, the depositional environment seems to represent an epeiric basin with restricted oceanic circulation. The basin may have been barred from ocean circulation by a series of horsts and ridges. Storm events may have temporarily oxygenated the previously anaerobic environments (Wignall and Myers 1988). The environment, as a whole, represented an environment alternating from episodically aerobic to anaerobic below fair-weather wavebase but above a storm wave-base in a middle offshore setting (Fig. 8). The Zoophycos ichnocoenosis is characterized by very high abundance and low diversity, including Phycosiphon incertum, Zoophycos isp., and Chondrites isp., which are indicative of an oxygen-limited environment with dysaerobic substrate conditions. The ichnocoenosis occurs with deep-water benthic foraminifera, relatively high concentration of planktonic foraminifers, and rarely macrobenthos. The benthic foraminifera assemblage in the Zoophycos ichnocoenosis contains significant amounts of calcareous foraminifers of agglutinated species, suggesting deposition of the host rocks within a dysaerobic environment (Tyszka 1994). The abundance of planktonic foraminifers of the Tsuku Formation is attributed to the presence of aerobic conditions in water masses due to open marine circulation. Simultaneously, ocean-current circulation may have induced bottom water agitation that resulted in a change from anaerobic (Scolicia ichnocoenosis) to dysaerobic environments (Zoophycos ichnocoenosis) on the substrate (Figs. 13a, b). In addition, the host deposits of the Zoophycos ichnocoenosis contain abundant glauconite, also indicating slightly reducing environment and low depositional rates. Therefore it is interpreted as being deposited during sea-level highstand (Fig. 13b), when sea level lay over the horst causing extensive ocean-current circulation. The depositional environments for the Early Oligocene deposits, from the Szeleng Sandstone to the Tsuku Formation, can be thus interpreted to represent a transgressive event from wave-dominated nearshore to a storm-dominated offshore environment. Within this depositional transition, these ichnofacies variations, from the Ophiomorpha to Zoophycos ichnocoenoses, are also interpreted as a natural response to a transgressive system during the Early Oligocene.

Subsequently, the well-documented middle Oligocene sea-level fall event occurred worldwide (Haq et al. 1987). The record of the lowstand event was inconspicuously recognized in the studied succession (Fig. 13c). The Late Oligocene deposits, however, represent a regressive system from middle offshore to intertidal-subtidal. These deposits display a characteristic ichnofacies distribution that can be divided into Scolicia, Teichichnus and Ophiomorpha ichnocoenoses. Characteristic lithofacies changes in the Late Oligocene formations provide evidence for a regressive shallowing-upward succession. The ichnoassemblages represent a transition from the Cruziana ichnofacies to Skolithos ichnofacies, which is indicative of a shallowing-upward sequence. The sequential transition from the Zoophycos to Scolicia ichnocoenoses represents a decreasing oxygenation in bottom water (Fig. 13d). These types of 
depositional systems gradually filled the Hsuehshan Trough during the Early Miocene (Fig. 13e). Depositional environments varied from a storm-dominated middle offshore to a tidedominated nearshore. The sequential variation of ichnoassemblages is represented by the transition from the Scolicia, Teichichnus to Ophiomorpha ichnocoenoses, which represents a shallowing-upward and regressive coarsening-upward succession.

The Oligocene succession of the Hsuehshan Trough is interpreted as recording tide-, waveand storm-dominated depositional systems based on the sedimentary structures. The Oligocene formations consist of two successions, a lower deepening-upward and an upper shallowingupward succession. Coarse-grained sediments of the Late Eocene to earliest Oligocene were deposited throughout the Hsuehshan Trough. Early Oligocene fine-grained facies deposited in upper offshore to lower offshore environments during a sea-level highstand overlie the obviously coarse-grained deposits (Fig. 14). The succession exhibits a general fining-upward trend together with an increasing upwards of deposit-feeding structures and a decreasing upwards of suspension-feeding structures. Upsection increases in deposit-feeding structures are often used to recognize transgressive sequences in the stratigraphic record (e.g., Howard and Reineck 1981; Rigsby 1994). The muddy early Oligocene deposits are probably related to sediment starvation during sea-level rise. The transgressive deepening upwards succession reported here suggests that the trend is coincident with Early Oligocene global sea-level fluctuations.

The Upper Oligocene deposits exhibit a varied succession from storm-dominated offshore to tide-dominated nearshore environments. They display coarsening- and shallowingupward successions that suggest a gradual filling of accommodation space with the Hsuehshan Trough. The environmental variation of the Upper Oligocene succession is not well correlated with the worldwide eustatic fluctuations (Fig. 14). It is suggested that the depositional rate was greater than the subsidence rate during the Late Oligocene. Basin subsidence became retarded so that sediments prograded into the basin and gradually filled it up (Teng et al. 1991). In the back-stripping model, Chou (1992) showed that rapid sediment supply rate and tectonic subsidence characterize the Upper Oligocene succession. Therefore, the influence of tectonics and sedimentation are undoubtedly related to the relative sea-level changes and environmental variation in the Hsuehshan Trough.

\section{CONCLUSIONS}

Trace fossil distribution incompletely corresponds with the bathymetry in the marine environments. Water depth alone is not a major ecological factor, but it does influence controlling parameters such as hydraulic regime and dissolved oxygen content, among others. In this paper, integration of trace fossil, benthic molluscan, planktonic foraminifera, glauconite, and sedimentary structures can provide useful insight into water masses and bottom-water conditions. Based upon the discussion above, aeration of the bottom water may be the most important factor in trace fossil distribution. Decimeter-scale ichnocoenosis variation may reflect episodic short-term changes by several primary paleoceanographic conditions, controlled by climatic cycles (Savrda 1995). The many hundreds of meter-scale sedimentary units of each ichnocoenosis in this succession were deposited over $1-2$ million years. This time range 
Wen-Shan Chen

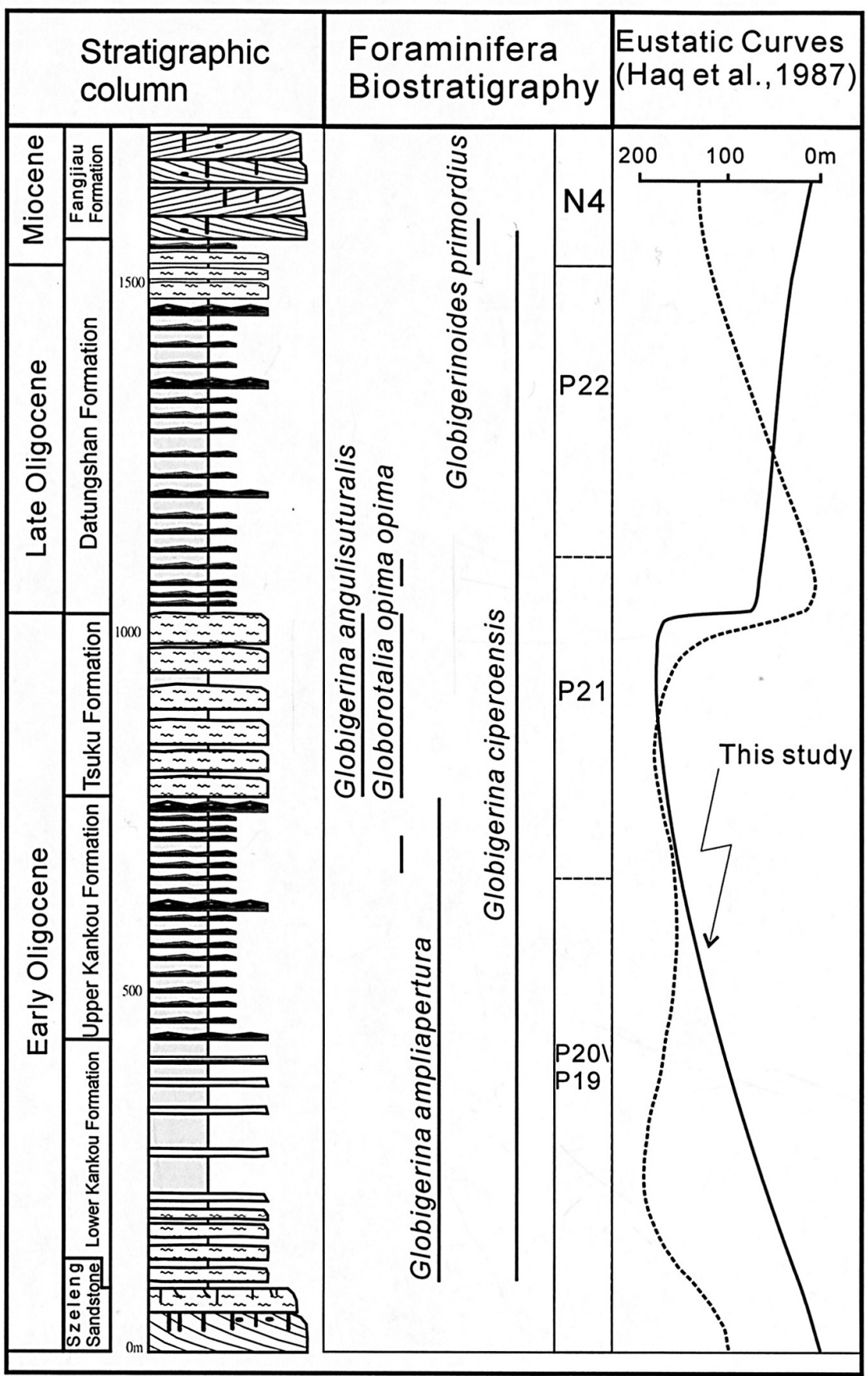

Fig. 14. Biostratigraphic and sequence-stratigraphic framework of the studied interval. Foraminifera biostratigraphy after Huang and Cheng (1983). 
indicates that these trends of the Oligocene succession may be controlled by paleoceanographic conditions that are closely linked to local tectonics and the longer-term of first-order sea-level fluctuations.

Acknowledgments This study was financially supported by National Science Council of Taiwan grant. We thank Professors Kenneth D. Ridgway and Yuan Wang for their constructive comments on the manuscript.

\section{REFERENCES}

Bromley, R. G., 1990: Trace fossils: Biology and Taphonomy. London, Unwin Hyman Ltd, $214 \mathrm{pp}$.

Bromley, R. G., and U. Asgaard, 1991: Ichnofacies: A mixture of taphofacies and biofacies. Lethaia, 24, 153-163.

Burkhalter, R. M., 1995: Ooidal ironstones and ferrugineous microbialites: Origin and relation to sequence stratigraphy (Aalenian and Baiocian, Swiss Jura Mountains). Sedimentology, 42, 57-74.

Cheel, R. J., and D. A. Leckie, 1993: Hummocky cross-stratification. In: Wright, V. P. (Ed.), Sedimentology Review/1, Oxford Blackwell Scientific., 103-122.

Chen, W. S., 1986: Trace fossils and depositional environment of the Lower Pitou Formation, Northeastern coast, Taiwan. Ti-Chih, 7, 65-81.

Chou, S. C., 1992: The Preliminary study of foreland-basin history in the western Taiwan. MS. Thesis, Natl. Taiwan Univ., Taipei, Taiwan, 64 pp.

Colquhoun, G. P., 1995: Siliciclastic sedimentation on a storm- and tide-influenced shelf and shoreline: The Early Devonian Roxburgh Formation, NE Lachlan fold belt, southeastern Australia. Sediment. Geol., 97, 69-98.

Corcoran, P. L., W. U. Mueller, and E. H. Chown, 1998: Climatic and tectonic influences on fan deltas and wave- to tide-controlled shoreface deposits: Evidence from the Archaean Keskarrah Formation, Slave Province, Canada. Sediment. Geol., 120, 125-152.

Duke, W., 1985: Hummocky cross-stratification, tropical hurricanes, and intense winter storms. Sedimentology, 32, 167-194.

Ekdale, A. A., and D. W. Lewis, 1991: Trace fossils and paleoenvironmental control of ichnofacies in a late Quaternary gravel and loss fan delta complex, New Zealand. Palaeogeogr., Palaeoclimat., Palaeoecol., 81, 253-279.

Frey, R. W., and T. V. Mayou, 1971: Decapod burrows in Holocene barrier island beaches and washover fans. Senckenbergiana Maritima, 4, 53-77.

Frey, R. W., and J. D. Howard, 1985: Trace fossils from the Panther Member, Star Point Formation (Upper Cretaceous), Coal Creek Canyon, Utah. J. Palaeont., 59, 370-404.

Frey, R. W., S. G. Pemberton, and T. D. A. Saunders, 1990: Paleontological notes, Ichnofacies and bathymetry: A passive relationship. J. Palaeont., 64, 155-158.

Fursich, F. T., 1975: Trace fossils as environmental indicators in the Corallian of England and Normandy. Lethaia, 8, 151-172. 
Fursich, F. T., and D. K. Pandey, 1999: Genesis and environmental significance of Upper Cretaceous shell concentrations from the Cauvery Basin, southern India.Palaeogeogr., Palaeoclimat., Palaeoecol., 145, 119-139.

Haq, B. U., J. Hardenbol, and P. R. Vail, 1987: Chronology of fluctuating sea levels since the Triassic. Science, 35, 1156-1167.

Howard, J. D., 1972: Trace fossils as criteria for recognizing shorelines in stratigraphic record. In: Rigby, J. K., and W. K. Hamblin, (Eds.), Recognition of Ancient Sedimentary Environ., Soc. Econ. Paleont., Mineral., Spec. Pub., 16, 215-225.

Howard, J. D., and H. E. Reineck, 1981: Depositional facies of high-energy beach-to-offshore sequence: Comparison with low-energy sequence. Am. Assoc. Petro. Geol. Bull., 65, 807-830.

Howard, J. D., and R. W. Frey, 1984: Characteristic trace fossils in nearshore to offshore sequence, Upper Cretaceous of east-central Utah. Canad. J. Earth Sci., 21, 200-219.

Huang, C. Y., and Y. M. Cheng, 1983: Oligocene and Miocene planktic foraminiferal biostratigraphy of northern Taiwan. Proc. Geol. Soc. China, 26, 21-56.

Johnson, H. D., and C. T. Baldwin, 1996: Shallow clastics seas: In: Reading, H. G., (Ed.), Sedimentary Environments. Processes, Facies and Stratigraphy (third edition), Blackwell Scientific Publ., 232-280.

Jones, B., and S. G. Pemberton, 1989: Sedimentology and ichnology of a Pleistocene unconformity-bounded, shallowing-upward carbonate sequence: The Ironshore Formation, Salt Creek, Grand Cayman. PALAIOS, 4, 343-355.

Lee, Y. T., 1983: Some consideration on the molluscan fauna in the Lungtung-Aoti section. Bull. Inst. Sci., Acad. Sinica, 3, 201-208.

Leckie, D. A., and R. G. Walker, 1982: Storm- and tide-dominated shoreline in Cretaceous Moosebar-lower Gates interval; outcrop equivalents of Deep Basin gas trap in Western Canada. Am. Assoc. Petro. Geol. Bull., 66, 138-157.

Lin, S. B., and C. D. Lin, 1993: Mineralogical properties and origins of the glauconitic and the chloritic peloids from Kuohsing area, central Taiwan. J. Geol. Soc. China, 36, 223243.

MacEachern, J. A., B. A. Zaitlin, and S. G. Pemberton, 1999: A Sharp-based Sandstone of the Viking Formation, Joffre Field, Alberta, Canada. Criteria for Recognition of Transgressively Incised Shoreface Complexes. J. Sediment. Res., 69, 876-892.

Miller, W. III, and E. H. Vokes, 1998: Large Phymatoderma in Pliocene slope deposits, northwestern Ecuador: Associated ichnofauna, fabrication, and behavioral ecology.Ichnos, 6, 23-45.

Moslow, T. F., and S. G. Pemberton, 1988: An integrated approach to the sedimentological analysis of some Lower Cretaceous shoreface and delta front sandstone sequences. In: James, D. P., and D. A. Leckie, (Eds.), Sequence, Stratigraphy, Sedimentology: Surface and Subsurface. Canad. Soc. Petro. Geol., Memoir 15.

Mueller, W., and E. Dimroth, 1987: A terrestrial-shallow marine transition in the Archean Opemisca Group east of Chapais, Quebec. Precambrian Res., 37, 29-55.

Olivero, D., and Gaillard, C., 1996: Paleoecology of Jurassic Zoophycos from south-eastern France. Ichnos, 4, 249-260. 
Pfluger, F., 1999: Matground Structures and Redox Facies. PALAIOS, 14, 25-39.

Richards, M. T., 1994: Transgression of an estuarine channel and tidal flat complex: The lower Triassic of Barles, Alpes de Haute Provence, France. Sedimentology, 41, 55-82.

Rigsby, C. A., 1994: Deepening-upward sequences in Oligocene and Lower Miocene fandelta deposits, western Santa Ynez Mountains, California.J. Sediment. Res., 64, 380391.

Rossetti, D. de F., 1997: Internal architecture of mixed tide- and storm-influenced deposits: An example from the Alcantara Formation, northern Brazil. Sediment. Geol., 14, 163188.

Savrda, C. E., 1995: Ichnologic Applications in Paleoceanographic, Paleoclimatic and Sealevel Studies. PALAIOS, 10, 565-577.

Savrda, C. E., R. E. Locklair, J. K. Hall, M. T. Sadler, M. W. Smith, and J. D. Warren, 1998: Ichnofabrics, Ichnocoenoses, and Ichnofacies Implications of an Upper Cretaceous TidalInlet Sequence (Eutaw Formation, Central Alabama). Ichnos, 6, 53-74.

Seilacher, A., 1964: Biogenic sedimentary structures. In: Imbrie, J., and N. Newell, (Eds.), Approaches to Paleoecology: Wiley, New York, 296-316.

Southard, J. B., J. M. Lambie, D. C. Federico, H. T. Pile, and C. R. Weidman, 1990: Experiments on bed configurations in fine sand under bidirectional purely oscillatory flow, and the origin of hummocky cross stratification. J. Sediment. Petro., 60, 1-17.

Tang, C. H., and C. Y. Yang, 1976: Mid-Tertiary stratigraphic break in the northeast Hsuehshan Range of Taiwan. Petro. Geol. Taiwan, 13, 139-147.

Tai, P. C., and L. S. Teng, 1994: Sequence stratigraphic analysis of the Oligocene strata, northern Taiwan. J. Geol. Soc. China, 37, 607-640.

Teng, L. S., 1992: Geotectonic evolution of Tertiary continental margin basin of Taiwan. Petro. Geol. Taiwan, 27, 1-19.

Teng, L. S., Y. Wang, C. H. Tang, and C. Y. Huang, 1991: Tectonic aspects of the Paleogene depositional basin of northern Taiwan. J. Geol. Soc. China, 34, 313-336.

Tyszka, J., 1994: Paleoenvironmental Implications from Ichnological and Microfauna Analyses of Bajocian Spotty Carbonates, Pieniny Klippen Belt, Polish Carpathians. PALAIOS, 9, 175-187.

Van Houten, F. B., and M. E. Purucker, 1984: Glauconite peloids and chamositic ooids-favorable factors, constraints, and problem. Earth Sci. Rev., 20, 211-243.

Wetzel, A., and R. G. Bromley, 1994: Phycosiphon incertum revisited: Anconichnus horizontalis its junior subjective synonym. J. Palaeont., 68, 1396-1402.

Wignall, P. B., and K. J. Myers, 1988: Interpreting benthic oxygen levels in mudrocks: A new approach. Geology, 16, 452-455.

Yuan, J. W., S. J. Lin, S. T Huang., and C. L. Shaw, 1985: Stratigraphic study on the PreMiocene under the Peikang Area, Taiwan. Petro. Geol. Taiwan, 21, 115-127. 